\title{
KEARIFAN LOKAL CERITA RAKYAT MASYARAKAT KABUPATEN KARIMUN KEPULAUAN RIAU
}

\author{
Julian Anggar Kesuma Siregar ${ }^{1}$, Abdul Malik², Dian Lestari ${ }^{3}$ \\ Pendidikan Bahasa dan Sastra Indonesia, Fakultas Keguruan dan Ilmu Pendidikan, Universitas \\ Maritim Raja Ali Haji \\ Pos-el: bobyjulian131@gmail.com
}

\begin{abstract}
Abstrak
Penelitian ini bertujuan mendeskripsikan kearifan lokal yang terefleksi dalam cerita rakyat masyarakat Kabupaten Karimun, Kepulauan Riau. Objek penelitian adalah cerita rakyat masyarakat Kabupaten Karimun yang didapatkan dari Informan. Metode penelitian ini adalah deskriptif dengan menggunakan pendekatan kualitatif. Teknik pengumpulan data yang digunakan adalah pengamatan, perekaman pencatatan, wawancara, dan pengalihan wacana. Teknik analisis data dilakukan dengan teknik analisis isi (content analysis). Hasil analisis data yang diperoleh dari cerita rakyat masyarakat Kabupaten Karimun Kepulauan Riau (Legenda Tanjung Gelam dan Tanjung Rambut, Kari Ikan Mentimun, dan Leban Bertuah) ditemukan kearifan lokal yang terefleksi berupa: pandangan hidup (filosofi), sikap hidup sosial, nasihat, iktibar, prinsip, norma, tata aturan sistem sosial, kebiasaan dan perilaku sehari-hari dalam pergaulan sosial.
\end{abstract}

Kata Kunci : Kearifan lokal, cerita rakyat, Karimun, Kepulauan Riau

\section{PENDAHULUAN}

Indonesia merupakan negara kepulauan yang kaya akan kebudayaan. Peran budaya dalam kehidupan masyarakat di Indonesia sangat besar, sehingga kebudayaan erat hubungannya dengan manusia yang dinobatkan sebagai penggeraknya. Kebudayaan diturunkan dari generasi ke generasi yang terus berkembang di kalangan masyarakat yang menjalankannya. Selain itu, perkembangan suatu kebudayaan tidak bisa dipisah dengan perkembangan sastra yang memiliki unsur bahasa dan kesenian. Hal itu banyak memberikan dampak yang bermanfaat terhadap masyarakat pendukung dalam perkembangan budaya.

Sastra terbagi dua, yaitu (1) sastra lisan dan (2) sastra tulisan. Sastra lisan adalah sastra yang sistem penyajiannya menggunakan media komunikasi lisan (tuturan), sedangkan sastra tulisan adalah cipta sastra yang disajikan dengan menggunakan media tulisan (Suhardi, 2011: 3). Keduanya memiliki perbedaan dalam bentuk media, akan tetapi memiliki peran yang sama untuk membangun pola pikir manusia. Pola pikir yang dimaksud dalam bentuk terefleksinya peran sastra ke dalam diri manusia, baik dalam berbudaya maupun bertingkah laku.

Adanya sastra lisan dalam kehidupan akan membuat seseorang dapat mengetahui sejarah, pengalaman, pandangan hidup, dan adat istiadat. Walaupun nilai-nilai yang terkandung tidak didapat secara langsung dengan jelas (tersirat), akan tetapi bisa dipahami apabila mendengar ceritanya. Hal ini berkaitan dengan peran sastra lisan (cerita rakyat) sebagai pemerkaya budaya yang mengandung nilai-nilai, etika, dan perilaku 
sebagai sumber yang disebut dengan kearifan lokal.

Keraifan lokal adalah bagian dari budaya milik masyarakat yang diwariskan secara turun-temurun dari satu generasi ke generasi melalui cerita dari mulut ke mulut. Warisan kebudayaan tersebut ada di dalam cerita rakyat, peribahasa, lagu, dan permainan rakyat yang tidak dapat dipisahkan dari bahasa milik suatu masyarakat. Menurut Rasidin dan Batubara (2009), ada lima bentuk kearifan lokal, yaitu (1) kearifan yang berupa pandangan hidup (filosofi); (2) kearifan berupa sikap hidup sosial, nasihat, dan iktibar yang diungkap dalam bentuk pepatah, perumpamaan, pantun, syair, atau cerita rakyat (folklor); (3) kearifan dalam seremoni atau upacara adat; (4) kearifan berupa prinsip, norma, dan tata aturan yang terwujud menjadi sistem sosial; (5) kearifan berupa kebiasaan, perilaku seharihari dalam pergaulan sosial. Pernyataan tersebut dapat disimpulkan bahwa kearifan lokal adalah nilai-nilai suci yang dikembangkan dan diwariskan untuk mengelola sumber daya (alam, manusia, dan budaya) secara turun-temurun oleh masyarakat lokal.

Indonesia memiliki 34 Provinsi, satu di antaranya Provinsi Kepulauan Riau. Provinsi Kepulauan Riau terdiri dari lima kabupaten, dua kota, 52 kecamatan serta 299 kelurahan/desa. Provinsi Kepulauan Riau, khusunya Kota Tanjungpinang, sudah tidak asing lagi dengan sebutan Kota Gurindam Negeri Pantun. Hal tersebut membuktikan Provinsi ini kaya akan kebudayaan khususnya sastra, baik sastra lisan maupun tulisan dan keberagaman budayanya dapat memperkaya identitas bangsa ini.

Penelitian Kearifan Lokal Refleksi Cerita Rakyat Masyarakat Kabupaten
Karimun Kepulauan Riau ini dilatarbelakangi oleh keberagaman cerita rakyat di Kepulauan Riau yang memiliki nilai kebudayaan tinggi. Namun sangat disayangkan bahwa kebudayaan yang tinggi tersebut sekarang ini seperti terlupakan. Pengaruh zaman yang semakin modern menjadi pemicu utama dalam merosotnya perkembangan cerita rakyat yang ada di Kepulauan Riau, khususnya di Kabupaten Karimun. Peran teknologi yang begitu besar membuat regenerasi tidak memedulikan lagi cerita rakyat daerah asalnya.

Di Kabupaten Karimun, banyak cerita rakyat yang masih belum diketahui banyak orang. Hal ini karena upaya pelestariannya masih minimalis, sehingga sukar diketahui keberadaan dan isi ceritanya. Kebanyakan orang di Kabupaten tersebut hanya mengetahui sebatas sejarah di tempat tinggalnya, bahkan ada yang sama sekali tidak mengetahui, sedangkan di Kabupaten yang terdiri dari 12 Kecamatan ini masih banyak cerita rakyat yang bisa merefleksi manusia dalam bentuk kearifan lokal di kehidupan sehari-hari. Hal tersebut mengakibatkan budaya lokal yang ada terancam hilang karena dalam penyebarannya tidak terlaksana dengan baik. Sementara itu pengetahuan tersebut penting bagi masyarakat Kabupaten Karimun juga Kepulauan Riau, bahkan Indonesia, apalagi bagi generasi penerus yang sedang berada di zona bahaya era globalisasi.

Demi mewujudkan perkembangan dan usaha mempertahankan budaya lokal yang terefleksi dalam cerita rakyat harus ada daya pemahaman yang luas dalam penyebarannya. Hal ini dilakukan agar bentuk pemahaman isi cerita rakyat juga pesan tersirat dan tersurat yang terdapat bisa tertanam dalam jiwa dengan baik 
kepada generasi penerus yang mulai melupakan budaya lokal. Hal tersebut dapat memperkuat tradisi bangsa ini guna melawan pengaruh era globalisasi yang bisa saja merusak generasi masa depan bangsa. Berdasarkan uraian temuan di atas, maka penelitian ini perlu dibahas secara detail mengenai Kearifan Lokal Refleksi Cerita Rakyat Masyarakat Kabupaten Karimun Kepulauan Riau.

\section{METODE PENELITIAN}

Pendekatan yang digunakan dalam penelitian ini adalah pendekatan kualitatif dan jenis penelitian ini deskriptif kualitatif. Penelitian ini berusaha mendeskripsikan suatu gejala, peristiwa, kejadian yang terjadi. Hal tersebut sejalan dengan Malik (2016:3), Penelitian deskriptif adalah pengkajian ilmiah yang dilakukan untuk memperoleh informasi tentang status gejala pada saat penelitian itu dilakukan sehingga dapat diperkirakan secara sistematis, baik dengan maupun tanpa menguji hipotesis, dan tanpa melakukan perlakuan terhadap variable-variabel yang diamati.

Dalam penelitian ini, Peneliti diharapkan dapat mendeskripsikan kearifan lokal yang terefleksi dalam cerita rakyat Kabupaten Karimun Kepulauan Riau yang terdapat di Pulau Karimun dan Kundur. Adapun cerita rakyat yang ditemukan saat turun ke lapangan ialah Legenda Tanjung Gelam dan Tanjung Rambut, Kari Ikan Mentimun, dan Leban Bertuah.

\section{Data dan Sumber Data}

Data dari penelitian ini berupa data kualitatif. Data yang ada lebih banyak dalam bentuk kata-kata. Data yang diperoleh dalam penelitian ini dari informasi lisan melalui informan cerita rakyat di Kabupaten Karimun Kepulauan Riau.

\section{Teknik Pengumpulan Data}

Peneliti menggunakan teknik
pengumpulan data dengan cara
pengamatan, perekaman pencatatan,
wawancara, dan pengalihan wacana.

\section{Teknik Analisis Data}

Teknik analisis data yang digunakan dalam penelitian ini teknik analisis isi (content analysis). Menurut Endraswara (2011: 161), "Teknik analisis isi merupakan teknik yang mengungkap, memahami, dan mengambil pesan-pesan yang terkandung dalam karya sastra. Pesan-pesan yang dimaksud berupa nilai-nilai seperti nilai religius, pendidikan, kearifan lokal, moral dan lain-lain".

a. Peneliti mengamati, melakukan perekaman, mencatat, menyusun, membaca, dan mengidentifikasi secara intensif data-data yang diperoleh dalam bentuk tulisan. Pada tahap ini akan menghasilkan serangkaian catatan termasuk kutipan cerita yang menjadi bukti analisis cerita rakyat masyarakat Kabupaten Karimun, Kepulauan Riau.

b. Peneliti menganalisis untuk menafsirkan makna yang ditemukan dalam cerita rakyat masyarakat Kabupaten Karimun Kepulauan Riau.

c. Peneliti menyimpulkan hasil analisis kearifan lokal yang terefleksi dalam cerita rakyat masyarakat Kabupaten Karimun Kepulauan Riau, dengan cara mendeskripsikan hasil dengan jelas.

\section{HASIL PENELITIAN DAN PEMBAHASAN}

\section{Kearifan Lokal yang Terefleksi dalam Cerita Rakyat Masyarakat Kabupaten Karimun Kepulauan Riau}

Kearifan lokal merupakan budaya suatu masyarakat yang diwariskan secara turuntemurun dari generasi ke generasi, kemudian dapat merefleksi kehidupan masyarakat sebagai bentuk pemahaman dan kebiasaan dalam kehidupan sehari-hari maupun pada waktu tertentu. Menurut Sibarani (2012: 123), "Kearifan lokal adalah pengetahuan asli (indigenous knowledge) atau kecerdasan lokal 
(localgenius) suatu masyarakat yang berasal dari nilai luhur tradisi budaya untuk mengatur tatanan kehidupan masyarakat dalam rangka mencapai kemajuan komunitas baik dalam penciptaan kedamaian maupun peningkatan kesejahteraan masyarakat". Dalam kajian kearifan lokal diklasifikasikan ke dalam lima bentuk, yaitu (1) kearifan yang berupa pandangan hidup (filosofi); (2) kearifan berupa sikap hidup sosial, nasihat, dan iktibar yang diungkap dalam bentuk pepatah, perumpamaan, pantun, syair, atau cerita rakyat (folklor); (3) kearifan dalam seremoni atau upacara adat; (4) kearifan berupa prinsip, norma, dan tata aturan yang terwujud menjadi sistem sosial; (5) kearifan berupa kebiasaan, perilaku seharihari dalam pergaulan sosial (Rasidin dan Batubara, 2009).

Kearifan lokal yang terefleksi dalam cerita rakyat Masyarakat Kabupaten Karimun Kepulauan Riau dilihat dari pandangan hidup (filosofi)

Terkait masalah pandangan hidup, masyarakat Kepulauan Riau, khususnya dalam penelitian ini adalah Masyarakat Kabupaten Karimun yang mayoritasnya orang Melayu, sudah dari zaman dahulu memegang teguh keyakinan pada kepercayaan tentang adanya kekuatan magis yang tidak dimiliki oleh manusia biasa. Walaupun pada awalnya masih mempercayai keberadaan dewa-dewa, dan benda-benda yang dianggap keberadaannya memiliki kekuatan sakti, seiring berjalannya waktu masyarakat Melayu Kabupaten Karimun, Kepulauan Riau, mulai mengarah pada kehidupan bernuansa Islam. Hal ini karena seluruh aktivitas mereka berlandaskan pada aturan agama Islam, sehingga tersebutlah adat bersendikan syarak, syarak bersendikan kitabullah. Artinya, seluruh aktivitas dan kehidupan Masyarakat Melayu berpedoman dengan ajaran dan aturan hukum Islam.

Dalam cerita rakyat "Tanjung Gelam dan Tanjung Rambut" ditemukan satu ajaran Islam, yaitu bersyukur. Hal tersebut merupakan bagian dari pandangan hidup masyarakat Kabupaten Karimun. Dari zaman dahulu hingga saat ini, mereka selalu bersyukur atas apa saja yang dialaminya. Temuan ini dapat dilihat dari kutipan cerita berikut ini.

Pada zaman dahulu ada sebuah kisah dua bersaudara yang akur di pesisir Pulau Karimun. Keduanya berkerja sebagai nelayan, sang Abang bertugas menjala, sedangkan Sang Adik bertugas mendayung. Setiap hari mereka selalu bersama ketika turun ke laut.

Penghasilan yang mereka dapatkan tidak pernah dijadikan permasalahan, baik itu cukup maupun tidak untuk memenuhi kehidupan sehari-hari. Mereka selalu bersyukur seberapa pun hasil tangkapan ikan yang mereka dapatkan. (Legenda Tanjung Gelam dan Tanjung Rambut)

Berdasarkan kutipan di atas, jelas terlihat kearifan lokal masyarakat Karimun Kepulauan Riau dilihat dari segi pandangan hidup (filosofi) yang dipegang teguh oleh masyarakatnya. Sikap bersyukur yang ditunjukkan oleh kedua tokoh dalam cerita rakyat tersebut mencerminkan diri seseorang tentang pandangan hidupnya yang berpedoman dengan agama Islam. Agama Islam merupakan pandangan hidup bagi masyarakat Karimun, Kepulauan Riau, yang menjadikan kehidupan mereka lebih terarah dan teratur. Andai saja hidup tanpa agama, sudah pasti akan terjadi banyak pertikaian dalam kehidupan sehari-hari.

Ditinjau lebih lanjut, kutipan cerita rakyat tersebut mencerminkan kekuatan pandangan Masyarakat Karimun, Kepulauan Riau, terhadap anugerah Ilahi. Dari cerita rakyat tersebut, terefleksi bahwa masyarakat selalu bersyukur setiap memperoleh hasil dari apa yang dilakukan 
dan dikerjakan, sebagaimana yang diperankan oleh tokoh Sang Abang dan Adik. Hal tersebut begitu sesuai dengan ajaran Islam yang tercantum dalam QS Ibrahim ayat 7 bahwa "Sesungguhnya jika kalian bersyukur, pasti Kami akan menambah (nikmat) kepada kalian; dan jika kalian mengingkari (nikmat-Ku), maka sesungguhnya azab-Ku sangat pedih".

Kutipan cerita yang hampir serupa juga ditemukan dalam cerita rakyat "Kari Ikan Mentimun". Hal tersebut memperjelas bahwa pandangan hidup (filosofi) tidak lepas dari ajaran dan aturan agama Islam. Dalam kutipannya mencerminkan sosok yang tetap bersyukur dan tidak lupa menjalani segala perintah yang Maha Kuasa. Adapun kutipan yang dimaksud sebagai berikut.

Seperti biasa, mereka setiap hari tetap turun ke laut untuk menjala ikan. Namun kala itu mereka bernasib tidak baik, karena hanya mendapatkan seekor ikan saja yang jika dijual hasilnya juga tidak cukup untuk makan. Mereka hanya bisa bersyukur meski tidak tahu harus berbuat apa setelahnya.

Tiba-tiba dengan tidak disangka oleh mereka, entah dari mana asalnya, yang pastinya atas kekuasaan yang Maha Kuasa. Mereka melihat ada mentimun hanyut kemudian terdampar di tepi laut di kala hari menjelang malam. Pemuda Suku Melayu itu turun dari atas batu, dan mengambil mentimun tersebut lalu dibawanya ke atas batu besar tempat di mana mereka sedang duduk berdua.

Setelah itu mereka langsung mengambil air wudhu yang kemudian menjalankan shalat Magrib di samping Batu Besar. Setelah shalat, mereka kembali duduk diam di atas batu. Beberapa saat setelah itu Pemuda Suku Melayu bersuara, "Tuan, mau kite apekan ikan dan mentimun ini?" Tanyanya.

"Masak kari saje ikan dengan mentimun ini, Tuan!" Jawabnya lembut.

\begin{abstract}
Akhirnya, mereka pun memasak kari ikan dan mentimun di atas batu besar. Berawal dari "Kari Ikan Mentimun" Pulau tersebut dinamai dengan Pulau Karimun, dan Batu Besar yang ada di tepi laut tersebut menjadi bukti peninggalan cerita yang disertakan dengan tempat mereka Shalat Fardu. Di sanalah mereka selalu bersama dalam susah dan senangnya kehidupan. (Kari Ikan Mentimun)
\end{abstract}

Merujuk pada kutipan di atas, selain sikap bersyukur yang ditunjukkan oleh kedua tokoh, dapat dilihat juga sikap gigih dan kesungguhannya dalam berusaha. Meski sikap tersebut tidak terlihat secara langsung pada hari di saat mereka hanya mendapatkan seekor ikan, tetapi jika disandingkan dengan perjalanan yang sudah dilalui keduanya, maka dapat diketahui bahwa keduanya adalah sosok yang gigih dan penuh kesungguhan. Mereka selalu berusaha, berdoa, dan tetap bersyukur meski hasil yang didapatkan tidak mencukupi.

Diteliti lebih jauh lagi kutipan tersebut juga mencerminkan sisi kehidupan yang tidak mudah menyerah meski sedang berada dalam situasi sulit. Masalah yang menjadi penderitaan selalu dihadapi dengan sabar dan diyakini akan ada jalan keluar. Hal itu jelas mencerminkan kekuatan iman yang tidak luntur kepada yang Maha Kuasa.

Penokohan yang tersirat dari tokoh Jalaluddin dan Pemuda Suku Melayu tersebut begitu sesuai dengan ajaran agama Islam. Allah sudah menjanjikan suatu 
kebaikan jika mahluknya selalu berusaha. Hal itu sesuai dengan QS Ar-Rad ayat 11 bahwa "Sesungguhnya Allah tidak akan mengubah nasib suatu kaum kecuali kaum itu sendiri yang mengubahnya". Selain itu juga diperjelas lagi bahwa segala sesuatu akan terasa mudah jika mau bersabar dan berusaha dalam menjalaninya. Pernyataan tersebut sesuai dengan QS Al-Insyirah ayat 5-6, "Maka sesungguhnya bersama kesulitan itu ada kemudahan. Sesungguhnya bersama kesulitan itu ada kemudahan".

Terakhir, ditemukan juga sikap bersyukur dalam cerita rakyat "Leban Bertuah". Dalam cerita tersebut mencerminkan karakter tokoh yang bersyukur kepada yang Maha Kuasa atas pertolongan yang didapatkan. Pertolongan yang dimaksud adalah perlindungan terhadap hutan rimba yang di dalamnya terdapat pohon besar. Adapun untuk memperjelas pernyataan tersebut, maka akan diuraikan peneliti berdasarkan kutipan berikut ini.

Keesokkan hari dan seterusnya,
Lanon itu tidak pernah kembali
lagi. Datuk pun bersyukur kepada
Tuhan yang Maha Esa karena telah
menunjukkan jalan kebaikan demi
kedamaian di dalam hutan tersebut.
Gemuruh besar dari lau yang
mendatangkan badai, sehingga
pohon Leban bertuah itu seolah
mengamuk menjadi pertanda
bahwa ketidakbaikan sedang
mengintip celah. Datuk pun berdoa,
dan atas izin yang Maha Kuasa
segalanya terjawab. (Leban
Bertuah)

Kutipan di atas, selain sikap bersyukur yang ditunjukkan oleh Datuk, sisi lain mencerminkan bahwa pertolongan yang Maha Kuasa tidak mungkin tidak ada. Jika diamati dengan baik, maka benar adanya bahwa niat jahat seseorang tidak akan berhasil karena sesungguhnya yang Maha Kuasa tidak tidur. Hal itulah yang membuat tokoh Datuk begitu yakin dan percaya bahwa jika ada yang berniat tidak baik di dalam hutan tersebut maka ia tidak akan selamat karena Tuhan Maha Tahu dan akan selalu melindungi apapun itu yang tidak bersalah dalam kehidupan ini.

Prinsip keyakinan dan kepercayaan tokoh Datuk tersebut tentang Tuhan yang mengetahui segalanya adalah bukti bahwa kebaikan, kejahatan, kejujuran, dan kebohongan tidak luput dari yang Maha Kuasa. Hal ini sesuai dengan QS Al-Imran ayat 29 bahwa "Katakanlah: jika kalian menyembunyikan apa yang ada di dalam dada kalian, atau kalian menampakkannya, maka Allah mengetahui semua itu. Allah mengetahui apa yang ada di langit dan apa yang ada di Bumi. Dan Allah Maha Kuasa atas segala sesuatu".

Berdasarkan seluruh uraian di atas, dapat dipahami bahwa kearifan lokal yang terefleksi dalam cerita rakyat Kabupaten Karimun, Kepulauan Riau, dilihat dari pandangan hidup (filosofi) yang hidup di zaman dahulu, lalu diwariskan secara turun-temururn telah menggambarkan betapa kuatnya ajaran Islam. Ajaran tersebut menjadi landasan pandangan hidup (filosofi) masyarakat Karimun, Kepulauan Riau. Sebab, masyarakatnya selalu berperilaku sesuai dengan ajaran dan perintah Allah.

\section{Kearifan lokal yang terefleksi dalam cerita rakyat Masyarakat Kabupaten Karimun Kepulauan Riau dilihat dari sikap hidup sosial, nasihat, dan iktibar}

Terkait masalah sikap hidup sosial, nasihat, dan iktibar masyarakat Kepulauan Riau, khususnya dalam penelitian ini adalah Masyarakat Kabupaten Karimun yang mayoritasnya orang Melayu, dalam cerita rakyat seringkali diselipkan di peranan tokoh dengan berperilaku baik yang disukai banyak orang dan perilaku buruk yang bisa menimbulkan kebencian orang lain. Di sisi lain juga perilaku buruk bisa dijadikan pelajaran untuk tidak bersikap demikian, sehingga dapat 
menghindari hal-hal buruk yang tidak disenangi banyak orang. Kearifan lokal terkait sikap hidup sosial, nasihat, dan iktibar yang terefleksi dalam cerita rakyat masyarakat Kabupaten Karimun, Kepulauan Riau, dapat dilihat pada kutipan-kutipan berikut ini.

\begin{tabular}{l} 
Alkisah seiring waktu yang terus \\
berjalan, tibalah di suatu hari yang \\
mengerikan. Sang Adik setiap \\
harinya selalu mewanti-wanti \\
kepada sang Abang untuk menjaga \\
$\begin{array}{l}\text { diri agar tidak bersiul sambil } \\
\text { mendendangkan sebuah lagu }\end{array}$ \\
\hline Lancang Kuning saat turun ke laut, \\
namun kala itu sang Abang lalai. \\
Hingga keduanya terlibat \\
perkelahian di atas sampan. \\
(Legenda Tanjung Gelam dan \\
Tanjung Rambut)
\end{tabular}

Kutipan di atas mencerminkan sebuah iktibar dan nasihat dari orang tua terdahulu yang seharusnya dipatuhi, tetapi menjadi tidak baik karena nasihat tersebut dilanggar oleh tokoh Abang yang lalai. Padahal setiap larangan yang disampaikan tentu ada landasannya. Para tetua yang menitip nasihat itu tentunya mengandung pesan yang sangat penting untuk kelangsungan hidup. Seperti nasihat untuk tidak bersiul dan mendendangkan lagu Lancang Kuning saat turun ke laut. Hal tersebut diyakini agar tidak terjadi hal-hal yang diinginkan seperti datang badai, tidak mendapatkan ikan saat menjala, dan lainlain yang bernilai kerugian.

Selain itu, ditemukan juga kutipan yang mencerminkan sikap kurangnya rasa hormat tokoh Adik saat bertutur kata dengan melantang menyebabkan kemarahan tokoh Abang, sehingga timbullah perselisihan yang akhirnya menjadi bencana bagi keduanya. Hal tersebut jelas menggambarkan sebuah nasihat dan menyiratkan cara sopan santun bahwa dalam bersikap dan berbicara perlu diperhatikan lebih baik lagi agar tidak menimbulkan rasa benci yang akhirnya mengakibatkan perselisihan.

Mendengar bantahan tersebut, Sang Adik langsung marah karena sudah melanggar petuah ketika sedang menjala, "Bang, Orang-orang Tue kite dulu selalu cakap kalau lagi turun jale tak boleh besiul, apelagi sampai bawe lagu Lancang Kuning. Kelak, kite tak dapat apeape turun ke laut, Bang," berkalikali pernyataan yang sama diucapkan lantang olehnya.

Akhirnya Sang Abang risih dan tidak terima karena tidak tahan dengan omelan Sang Adik yang tiada henti. Ia tidak suka dilaranglarang oleh adiknya, dan merasa apa yang dilakukannya hanya bentuk ketidaksengajaan. Ia tidak ingin disalahkan. Ia langsung memberontak dan terjadilah baku hantam, sehingga ia terjatuh ke laut (Legenda Tanjung Gelam dan Tanjung Rambat).

Selanjutnya, terkait dengan sikap hidup sosial, masyarakat Kabupaten Karimun, Kepulauan Riau dapat dilihat dalam cerita rakyat "Kari Ikan Mentimun" yang menyiratkan hubungan antar sesama manusia untuk selalu saling menyayangi dan perhatian satu sama lain. Jika ada orang yang membutuhkan bantuan, hendaknya yang lain membantu sehingga terjalinlah bentuk hubungan yang harmonis dari sikap kepedulian dan saling melengkapi itu. Hal tersebut dapat dilihat dari kutipan berikut ini.

Jalaluddin sedang duduk di atas batu yang sangat besar. Ia menceritakan sebab-akibat sampainya di Pulau tersebut dan menyatakan bahwa ia juga sedang kelaparan. Pemuda itu terharu, namun malangnya pada hari itu ia ternyata sama sekali belum mendapatkan ikan. 
Mendengar cerita pedagang yang terdampar tersebut, ia langsung bergegas membawanya ke suatu daerah yang sekarang bernama Pangke (Orang Kaya). Pemuda itu ingin memperkenalkan Jalaluddin kepada salah satu orang terkaya di Pulau tersebut. Pemuda itu menceritakan bahwa Orang Kaya itu memiliki harta yang tiada habisnya. Kesehariannya hanya menjemur uang di atas tikar dari satu rumah ke rumah yang lainnya (Kari Ikan Mentimun).

Melihat kutipan di atas, maka niat baik Pemuda Suku Melayu yang ingin mengenalkan Jalaluddin kepada Orang terkaya di daerah Pangke adalah bukti kuat bahwa sikap saling membantu menjadi kearifan lokal dilihat dari kepedulian sosial yang terefleksi dari cerita rakyat tersebut. Tokoh Pemuda Suku Melayu tersebut menunjukkan sikap pedulinya setelah mendengar cerita Jalaluddin terdampar dan kelaparan. Meski saat itu ia tidak bisa membantu secara material, tetapi ia berusaha membantu mencari solusi. Hal tersebut juga mencerminkan sikap kepedulian sosial masyarakat Kabupaten Karimun Kepulauan Riau di masa kini bahwa berbuat baik dan saling membantu sesama selalu dilakukan masyarakatnya.

Selain kutipan di atas, sikap hidup sosial juga tersirat dalam kutipan lain di dalam cerita rakyat "Kari Ikan Mentimun" ketika Jalaluddin dan Pemuda Suku Melayu mencari pertolongan untuk mengobati para warga yang diserang Tuma (Kutu). Sikap tersebut menyatakan betapa pedulinya mereka terhadap sesama yang membutuhkan pengobatan. Hal ini juga masih berlaku hingga sekarang di kalangan masyarakat Kabupaten Karimun bahwa sikap tolong-menolong adalah sesuatu yang menjadi kebiasaan bagi sesama manusia. Berikut ini kutipan yang dimaksud.
Setelah itu mereka mendapatkan suatu musibah. Beberapa warga yang membongkar hutan ketika mereka pulang, di tengah jalan tubuhnya gatal-gatal. Ternyata baju yang mereka kenakan terdapat banyak Tuma (kutu). Jalaluddin meminta pemuda Suku Melayu itu mencari air hangat (Kari Ikan Mentimun).

Di sisi lain, terkait sikap hidup sosial, nasihat, dan iktibar, dalam cerita rakyat "Leban Bertuah" juga ditemukan cerminan perilaku yang terefleksi. Adapun cerminan yang dimaksud akan diurai berdasarkan kutipan berikut ini.

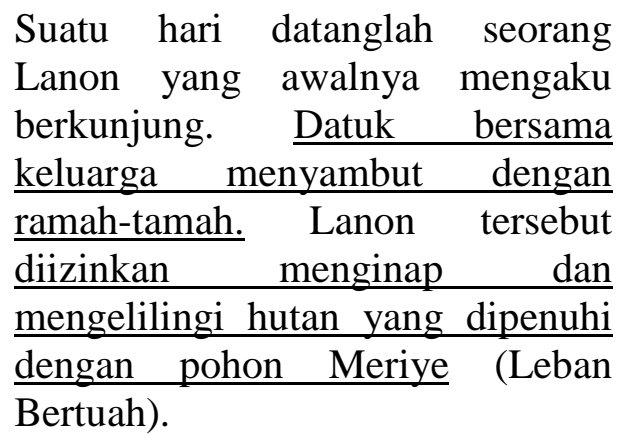

Kutipan di atas menjelaskan sikap peduli terhadap sesama dan sopan santun dari tokoh Datuk kepada tamu yang ternyata Lanun. Hal tersebut mencerminkan bahwa meski awalnya belum saling mengenal tetapi karena memiliki rasa peduli terhadap sesama, Datuk tidak menolak untuk membantu tamu tersebut yang ingin menginap dan bahkan ia tidak acuh justru ramah-tamah. Sikap yang seperti itu juga hingga sekarang masih arif dilakukan oleh Masyarakat Kabupaten Karimun. Meski terkadang belum saling kenal, tetapi untuk sebuah kebaikan tetap dilakukan.

Berdasarkan beberapa kutipan dan penjelasan di atas, dengan demikian dapat disimpulkan bahwa kearifan lokal yang terefleksi dalam cerita rakyat Masyarakat Kabupaten Karimun, Kepulauan Riau dilihat dari sikap hidup sosial, nasihat, dan iktibar dari zaman dahulu masih berlaku 
hingga sekarang. Hal tersebut dapat dilihat dengan masih banyaknya para Nelayan menjaga petuah, yakni tidak bersiul dan mendendangkan lagu Lancang Kuning saat turun ke laut. Di samping itu pada sisi sikap hidup sosial juga terlihat dari cara masyarakat Melayu Kabupaten Karimun dalam menjaga sopan dan santun saat bertutur kata. Selain itu juga tidak bisa dipungkiri bahwa sikap saling membantu sesama manusia hingga sekarang masih dilakukan oleh Masyarakat Kabupaten Karimun, Kepulauan Riau.

\section{Kearifan lokal yang terefleksi dalam cerita rakyat Masyarakat Kabupaten Karimun Kepulauan Riau dilihat dari prinsip, norma, dan tata aturan yang terwujud menjadi sistem sosial}

Kearifan lokal yang dilihat dari prinsip, norma, dan tata aturan dalam cerita rakyat Masyarakat Kabupaten Karimun, Kepulauan Riau dapat dilihat dari cerita rakyat "Tanjung Gelam dan Tanjung Rambut". Cerita ini mengisahkan tentang dua bersaudara yang hidup rukun, kemudian kerukunan itu hancur akibat sedikit adanya perselisihan. Dalam keterkaitannya dengan kearifan lokal yang terrefleksi dilihat dari prinsip, norma, dan tata aturan adalah ketika tokoh Abang tenggelam di laut, dan yang dapat ditemukan oleh tokoh adik hanya tujuh helai rambutnya saja.

Setelah hanya menemukan tujuh helai rambut, tokoh Adik langsung memakamkan ketujuh helai rambut tersebut di sekitaran rumahnya. Hal tersebut mencerminkan prinsip kemanusiaan dan norma kehidupan bahwa setiap yang meninggal dunia haruslah dimakamkan sebagaimana mestinya dengan aturan Agama yang dianut. Meskipun jasadnya tidak dapat ditemukan tetapi demi kebaikan dan bentuk penghormatan, maka tokoh Adik dalam cerita tersebut tetap memakamkan dari yang ia temukan. Hal ini dapat dilihat dalam kutipan berikut.

Saat itu juga ia langsung
memakamkan ketujuh helai rambut
di dekat rumahnya. Makamnya
ditata rapi dengan dua buah batu
nisan dari batu yang ia ambil di
pesisir (Tanjung Gelam dan
Tanjung Rambat).

Berdasarkan kutipan tersebut, jelas tergambar betapa kuatnya prinsip kemanusian dan norma kehidupan yang ditunjukkan oleh tokoh Adik. Hal itu tidak jauh berbeda dari keberlangsungan kehidupan di Masyarakat Kabupaten Karimun di zaman sekarang bahwa setiap yang meninggal dunia sudah pasti akan dimakamkan sesuai dengan tata aturan agama. Terlepas dari itu, hal ini juga bagian dari prinsip kemanusiaan dalam menjalani kehidupan.

Di sisi lain, berdasarkan penjelasan di atas juga memiliki keterikatannya dengan sistem sosial dalam cerita rakyat tersebut. Hal ini dikatakan karena makam dari tokoh Abang dijadikan sebagai pembatas wilayah dengan diberi nama makam Tuk Jambul. Selain itu, makam tersebut dirawat oleh Masyarakat dan dijadikan keramat dengan bangunan bernuansakan Melayu, yakni berwarna kuning. Muatan kearifan lokal yang terefleksi tersebut dapat dilihat dari kutipan berikut ini.

Sejak saat itu makam yang terdapat di daerah tersebut menjadi garis pembatas wilayah Tanjung Gelam dan Tanjung Rambut. Makam tersebut pun diberi gelar Makam Tuk Jambul. Masyarakat setempat juga mengatakan bahwa nama Tanjung Gelam diambil dari kisah sang Abang yang tenggelam, sedangkan Tanjung Rambut dari tujuh helai rambut yang ditemukan.

Makam tersebut kini dijadikan Keramat Tanjung Gelam dan dibuatkan pondok untuk 
melindungi makam tersebut dari hujan dan kepanasan. Pondoknya berbentuk segi empat dengan atap kerucut dan dinding kawat mata punai, sehingga makam yang terdapat di dalamnya bisa terlihat tanpa memasuki ruangan. Warna pondok tersebut berwarna khas nuansa Melayu, yaitu kuning.

Makamnya sekarang sudah dikeramik berwarna putih terdiri dari tiga lapisan yang melambangkan kedudukan sosial si tokoh semasa hidupnya. Sejak itu makam tersebut juga menjadi pembatas wilayah Tanjung Gelam dan Tanjung Rambut yang sekarang semakin dikenal dengan sebutan Costal Area sebagai tempat wisata untuk menikmati suasana tepi laut yang indah di Pulau Karimun (Tanjung Gelam dan Tanjung Rambat).

Berdasarkan kutipan-kutipan di atas, maka bisa dipahami bahwa sistem sosial yang terefleksi dalam cerita rakyat tersebut memiliki keterkaitan yang erat dengan kehidupan di Masyarakat Kabupaten Karimun. Hal tersebut dapat dilihat dari bangunan pondok yang dibangun dengan bernuansakan Melayu. Seperti yang diketahui bahwa di Kabupaten Karimun, Kepualauan Riau, penduduknya mayoritas suku Melayu. Hal ini jelas menjadi bukti dalam bentuk melestarikan kearifan lokal yang terefleksi dalam cerita rakyat tersebut dalam upaya menjaga keutuhannya.

Membahas sistem sosial dalam kehidupan yang terlihat dalam cerita rakyat, maka ditemukan kembali cerminan tersebut dalam cerita rakyat "Kari Ikan Mentimun". Di dalam ceritanya menceritakan hidup bergotong royong yang dilakukan oleh masyarakatnya. Pernyataan tersebut dapat dilihat kejelasannya dari kutipan berikut ini.
Meninggalnya orang terkaya di Pulau tersebut membuat semua warga yang ada jatuh miskin. Demi menyambung kehidupan, akhirnya mereka sepakat membongkar hutan rimba yang ada di sana untuk dijadikan lahan pertanian dan sebagiaannya. Berbondongbondong mereka semua bergotong royong membongkar hutan rimba yang sekarang daerah tersebut dinamakan Pongkar (Kari Ikan Mentimun).

Berdasarkan kutipan di atas, hal itu juga memiliki keterkaitan yang erat dalam kehidupan sehari-hari masyarakat Kabupaten Karimun hingga sekarang. Kegiatan tersebut merupakan cerminan sistem sosial yang masih dilestarikan dalam kegiatan-kegiatan yang biasanya diadakan di suatu daerah Kabupaten Karimun, seperti kegiatan bergotong royong saat membangun Masjid atau rumah Ibadah lainnya, menerapkan sistem kebersihan di pinggir jalan, dan lain sebagiannya. Jika dipahami lagi lebih lanjut dari uraian sebelumnya, maka kearifan lokal yang terefleksi dalam cerita rakyat masyarakat Kabupaten Karimun, Kepulauan Riau, masih terjaga dan dilestarikan oleh Masyarakatnya. Hal ini juga sesuai dengan tata aturan yang diberlakukan oleh pihak pemerintah daerah tersebut.

Kearifan lokal yang terefleksi dalam cerita rakyat Masyarakat Kabupaten Karimun Kepulauan Riau dilihat dari dari kebiasaan dan perilaku sehari-hari dalam pergaulan sosial

Banyak kebiasaan dan perilaku di kehidupan sehari-hari masyarakat Kabupaten Karimun, Kepulauan Riau, tetapi di antara itu semua yang paling menonjol yang terefleksi dalam cerita rakyat adalah kebiasaan makan bersama sebagai bentuk berbagi atas berkah yang diperoleh. Hal itu mencerminkan sebuah 
situasi keakraban dan kekompakan yang menyatukan satu sama lain. Berikut ini akan dipaparkan kutipan yang mencerminkan situasi tersebut.

Akhirnya, mereka pun memasak
kari ikan dan mentimun di atas batu
besar yang kemudian mereka
nikmati bersama. Berawal dari
"Kari Ikan Mentimun" Pulau
tersebut dinamai dengan Pulau
Karimun, dan Batu Besar yang ada
di tepi laut tersebut menjadi bukti
peninggalan cerita yang disertakan
dengan tempat mereka Shalat
Fardu. Di sanalah mereka selalu
bersama dalam susah dan
senangnya kehidupan (Kari Ikan
Mentimun).

Merujuk pada kutipan di atas, dapat dilihat bentuk kebersamaan, keakraban, dan kekompakan antara kedua tokoh. Mereka tetap bersama dalam susah dan senangnya kehidupan. Selain itu, berapapun hasil yang didapatkan dari pekerjaannya mereka tetap saling berbagi. Hal itu tergambar dari bagaimana cara mereka menikmati ikan di masak kari bersama

Demikianlah cerminan masyarakat Kabupaten Karimun, Kepulauan Riau dari zaman dahulu hingga saat ini. Mereka senang berkumpul, senang berbagi sesama, dan tidak ada saling membeda-bedakan. Dengan demikian, apapun suku, ras, dan agamanya, siapapun mereka dapat duduk bersama. Contoh di masa sekarang yang bisa dilihat dengan jelas adalah ketika para generasi muda berkumpul. Hal tersebut tidak hanya berdiskusi untuk suatu tujuan yang ingin mereka capai, melainkan juga bagi yang punya penghasilan lebih selalu berbagi dalam bentuk makanan yang bisa dinikmati bersama. Situasi itu menandakan betapa mereka tetap berbagi meski yang berkumpul belum tentu suku, ras, dan agamanya sama.

Selanjutnya, kearifan lokal lain yang terkandung dalam cerita rakyat
Masyarakat Kabupaten Karimun adalah kebiasaan perilaku sehari-hari dalam mengupayakan mata pencaharian bagi mereka yang hidup di tepi Pantai. Sejak zaman dahulu hingga di awal masa kemerdekaan, dan bahkan hingga sekarang, Masyarakat Kabupaten Karimun, Kepulauan Riau yang tinggal di tepi Pantai bekerja sebagai nelayan. Hal tersebut dapat dilihat pada kutipan berikut ini.

Pada zaman dahulu ada sebuah kisah dua bersaudara yang akur di pesisir Pulau Karimun. Keduanya berkerja sebagai nelayan, sang Abang bertugas menjala, sedangkan Sang Adik bertugas mendayung. Setiap hari mereka selalu bersama ketika turun ke laut (Tanjung Gelam dan Tanjung Rambut).

Berdasarkan kutipan di atas, pada zaman dahulu pekerjaan nelayan sudah ada yang melakukannya. Hal itu bukanlah suatu hobi karena hidup di tepi pantai, melainkan pekerjaan demi menjalani kehidupan sehari-hari dalam mengupayakan mata pencaharian. Hingga di zaman sekarang juga tidak sulit untuk menemukan orang-orang yang tinggal di pantai dengan pekerjaannya sebagai Nelayan.

Selain kutipan cerita di atas, bentuk refleksi kearifan lokal berupa kebiasaan dan perilaku sehari-hari Masyarakat Kabupaten Karimun, Kepulauan Riau, juga tercermin dalam cerita rakyat "Kari Ikan Mentimun" dan "Leban Bertuah". Di dalam cerita tersebut juga ada tokoh yang berprofesi sebagai Nelayan. Pada cerita rakyat "Kari Ikan Mentimun" ada sosok Pemuda Suku Melayu dan Jalaluddin yang bersahabat. Kehidupan mereka sehari-hari dalam melangsungkan hidup, yakni turun ke laut. Sedangkan di dalam cerita rakyat "Leban Bertuah" diceritakan tentang seorang Nelayan yang sedang beristirahat di tepi pantai karena angin kencang di 
tengah laut. Kedua penjelasan tersebut dapat dilihat pada kutipan di bawah ini.

Suatu hari, Jalaluddin yang sudah tinggal menetap di sana profesinya berubah menjadi nelayan karena bersahabat baik dengan Pemuda Suku Melayu. Seperti biasa, mereka setiap hari tetap turun ke laut untuk menjala ikan. Namun kala itu mereka bernasib tidak baik, karena hanya mendapatkan seekor ikan saja yang jika dijual hasilnya juga tidak cukup untuk makan. Mereka hanya bisa bersyukur meski tidak tahu harus berbuat apa setelahnya (Kari Ikan Mentimun).

Keesokan harinya, tepat di hari ketiga Lanon itu berada di dalam hutan. Datuk mendengar sebuah kabar dari salah satu nelayan yang kala itu sedang beristirahat di tepi laut. Datuk yang sedang mengelilingi hutan, menghampirinya ketika melihat ada seorang yang sedang bersandar lelah di sebuah pohon besar (Leban Bertuah).

Selain menjalani kehidupan sehari-hari dengan mengupayakan mata pencaharian sebagai nelayan, bagi masyarakat Kabupaten Karimun yang tinggal di daratan banyak yang bekerja sebagai petani. Ada yang menanam sayur-mayur, buah-buahan, dan ada juga yang bekerja sebagai petani karet. Mereka berupaya mengelola alam dengan sebaik mungkin untuk mendapatkan penghasilan yang diinginkan. Cerminan kearifan lokal yang terefleksi dalam cerita rakyat Masyarakat Kabupaten Karimun tersebut dapat dilihat pada kutipan berikut ini.

Meninggalnya orang terkaya di Pulau tersebut membuat semua warga yang ada jatuh miskin. Demi menyambung kehidupan, akhirnya mereka sepakat membongkar hutan rimba yang ada di sana untuk dijadikan lahan pertanian dan sebagiaannya. Berbondongbondong mereka semua bergotong royong membongkar hutan rimba yang sekarang daerah tersebut dinamakan Pongkar (Kari Ikan Mentimun).

Merujuk kutipan di atas, jika dipahami dengan teliti, maka setelah hutan itu dibongkar dan dijadikan lahan, maka banyak warga yang kala itu bekerja sebagai petani. Memang di dalam kutipan tersebut tidak dijelaskan profesi petani dalam bidang apa, tetapi dapat dibayangkan hutan yang rimba tersebut tentu luas, sehingga lahan yang dibuka cukup untuk dijadikan tempat bercocok tanam seperti sayur-mayur dan buahbuahan.

Selain di dalam cerita rakyat "Kari Ikan Mentimun" kearifan lokal yang terefleksi dilihat dari kebiasaan dan perilaku seharihari pada mata pencaharian sebagai petani juga ditemukan dalam cerita rakyat "Leban Bertuah". Tokoh Datuk yang tinggal bersama keluarganya di dalam hutan rimba merupakan tokoh yang disebutkan profesinya pada masa itu sebagai petani karet. Hal ini dapat dilihat dari kutipan berikut ini.

Dahulu kala, ada sumpah yang diucapkan oleh seorang Datuk yang bekerja sebagai petani karet di sebuah hutan rimba yang dipenuhi dengan pohon Meriye dan satu pohon besar yaitu pohon Leban. Sumpah tersebut dikatakan olehnya karena ada niat buruk seorang Lanon yang melarikan diri dari Pulau Karimun (Leban Bertuah).

Berdasarkan kutipan di atas, tokoh Datuk yang bekerja sebagai petani karet sesuai juga dengan kehidupan Masyarakat Karimun, Kepulauan Riau di zaman sekarang, khususnya lagi di Pulau Kundur, tepat di mana cerita rakyat ini berasal. Di 
Pulau Kundur, pada umumnya hampir semua masyarakatnya yang tinggal di daratan bekerja sebagai petani karet. Jika disandingkan dengan cerita rakyat tersebut, tampak jelas bahwa kearifan lokal yang terefleksi dilihat dari kebiasaan dan perilaku sehari-hari dalam mengupayakan mata pencaharian masih utuh. Dengan demikian dapat dipahami bahwa muatan kearifan lokal ini masih dilakukan oleh masyarakatnya.

Merujuk dari keseluruhan pemaparan beberapa kutipan dan penjelasan di atas, dapat diketahui dengan pemahaman yang luas bahwa kearifan lokal yang terefleksi dalam cerita rakyat masyarakat Kabupaten Karimun, Kepulauan Riau dilihat dari kebiasaan dan perilaku sehari-hari dalam pergaulan sosial hingga saat ini masih hidup dan berkembang di dalam kehidupan Masyarakat Kabupaten Karimun, Kepulauan Riau. Masyarakatnya senang berbagi sesama, hidup bersama, dan membangun kebersamaan hingga terciptalah keakraban dan kekompakan. Selain itu, mereka juga menjaga dan tetap melestarikan kearifan lokal dalam mengupayakan mata pencaharian dengan baik sesuai dengan profesinya yang menjadi nelayan maupun petani.

\section{SIMPULAN}

Penelitian ini membahas kearifan lokal yang terefleksi dalam cerita rakyat. Adapun cerita rakyat yang diteliti berdasarkan data-data yang didapatkan adalah Tanjung Gelam dan Tanjung Rambut, Kari Ikan Mentimun, dan Leban Bertuah. Hal tersebut akan dipaparkan melalui simpulan di bawah ini.

Kearifan lokal yang direfleksikan dalam cerita rakyat yang ditemukan dari ketiga cerita tersebut dilihat dari pandangan hidup (filosofi) berpedoman pada ajaran agama Islam. Dilihat dari sikap hidup sosial, nasihat, dan iktibar ditemukan bentuk kearifan lokal sikap saling peduli satu sama lain, sopan santun, dan pantang larang. Dilihat dari prinsip, norma, dan tata aturan sistem sosial ditemukan bentuk kearifan lokal sikap peri kemanusiaan dan kehidupan bernuansakan Melayu, dan bergotong royong. Terakhir, dilihat dari kebiasaan dan perilaku sehari-hari dalam pergaulan sosial ditemukan kearifan lokal kebersamaan, keakraban, kekompakan, dan mengupayakan mata pencaharian (nelayan dan petani).

\section{DAFTAR PUSTAKA}

Endraswara, Suwardi. 2011. Metodologi Penelitian Sastra. Yogyakarta: CAPS.

Malik, Abdul. 2016. Penelitian Deskriptif untuk Bidang Prndidikan, Sastra,dan SosialBudaya.Tanjungpinag. FKIP Universitas Maritim Raja Ali Haji.

Malik, Abdul. 2018. Materi Kuliah Penalitian Pengajaran Bahasa Indonesia. Tanjungpinang. FKIP Universitas Maritim Raja Ali Haji.

Rasyidin, Al., dkk. 2009. "Penyerapan Nilai-nilai Budaya Lokal dalam kehidupan beragama di Medan: Studi tentang Budaya Lokal di Medan" dalam Afii dan Bahri, Saeful. Harmonisasi Agama dan Budaya Di Indonesia. Jakarta: Balitbang Kemenag.

Sibarani, Robert. 2012. Kearifan Lokal (Hakikat, Peran, dan Metode Tradisi Lisan). Jakarta: Asosiasi Tradisi Lisan (ATL).

Suhardi. 2011. Sastra Kita, Kritik, dan Lokalitas. Depok: Komodo Books.

Suhardi. 2017. "Analisis Nilai-Nilai Budaya (Melayu) Dalam Sastra Lisan Masyarakat Kota Tanjungpinang”.

Dikutip dari http://journal.unnes.ac.id Lingua/article/view/8755. 
Siregar, Malik, \& Lestari: Kearifan Lokal ...

Suhardi. 2018. "Nilai Budaya Minangkabau Dalam Cerpen 'Cimuntu Lansie' Karya Wisran Hadi”. Dikutip dari http://ejournal.iaintulungagung.ac.id $\mathrm{hp} / \mathrm{is} /$ article/view/810.
Suhartono., dkk. 2010. Cerita Rakyat di Pulau Mandangin: Kajian Struktural Antropologi Claude Lévi Strauss. Jurnal Fakultas Bahasa dan Seni Universitas Negeri Surabaya: Vol 23, Nomor 4, hlm. 304-311. 